\title{
Katsaus
}

Miia Kosonen, Salla-Maaria Laaksonen, Henrik Rydenfelt \& Anja Terkamo-Moisio

\section{Sosiaalinen media ja tutkijan etiikka}

Tuottaakseen uutta tietoa tutkijan on oltava ajassa kiinni ja voitava kerätä ja käyttää erilaisia aineistoja. Sosiaalisen median käyttö tutkimuksessa on yleistynyt nopeasti. Siihen liittyvien tutkimuseettisten näkökohtien arviointi on kuitenkin osoittautunut haasteelliseksi osittain vähäisen kokemuksen, ympäristöjen nopean kehityksen sekä Internet-tutkimukseen liittyvien eettisten kysymysten monitahoisuuden vuoksi (esim. Markham \& Buchanan 2012). Vaikka Internet-tutkimuksen etiikkaa on pohdittu 90-luvulta alkaen (ks. Turtiainen \& Östman 2013), sosiaalisen median käytön yleistyminen sekä aineistojen saatavuus erilaisten rajapintojen kautta ovat tuottaneet uusia eettisiä kysymyksiä (vrt. Zimmer \& Kinder-Kurlanda 2017; Zimmer 2015). Sosiaalisen median tutkimusetiikkaan liittyvä kirjallisuuden määrä on kasvussa, mutta yleisesityksiä aiheesta on saatavilla vähän. Vakiintuneet hyvät käytännöt ovat pitkälti vielä selvittämättä ja kehittymättä.

Association of Internet Researchers (AoIR) ${ }^{1}$ julkaisi vuonna 2012 Internetissä tehtävää tutkimusta koskevan eettisen suosituksen (Markham \& Buchanan 2012). Suositus ei anna yksityiskohtaisia ohjeita vaan nostaa esiin seikkoja, joita tutkijan tulisi pohtia toteuttaessaan tutkimusta sosiaalisessa mediassa sekä Internetissä. Suositus korostaa ympäristöjen jatkuvaa muutosta. Jokainen esiin nouseva kysymys tulisi arvioida tapauskohtaisesti. Samoin Östman ja Turtiainen (2016) ovat esittäneet, että tarkkojen eettisen ohjeistuksien asemesta olisi syytä tutkia ja reflektoida tutkimusetiikkaa osana tutkimusprosesseja.

Uudenlaiset aineistot tai tutkimusaineistot eivät vähennä tutkimuseettisen harkinnan tärkeyttä, pikemminkin päinvastoin (ks. Zimmer \& Kinder-Kurlanda 2017). Eettisessä arvioinnissa tutkijan toimintaa rajoittavat monet tekijät, jotka on otettava huomioon tutkimustyön jokaisessa vaiheessa. Tutkimuksen etiikassa painottuvat erityisesti tutkittavien ihmisyksilöiden vapaudet ja oikeudet. Tutkittavaksi kaavailluille on usein annettava mahdollisuus tehdä oma, itsenäinen ja tietoon pohjautuva päätös osallistumisestaan tutkimukseen. Yksilön oikeuksista korostuu erityisesti oikeus yksityisyyteen, jota tutkimuksen tekeminen ja sen tulosten julkaiseminen voi rikkoa.

Tutkimuseettisen neuvottelukunnan (TENK) laatima ohjeistus ihmistieteiden eettisestä ennakkoarvioinnista ${ }^{2}$ lähtee kolmesta ihmistieteellisen tutkimuksen eettisestä periaatteesta: tutkittavan itsemääräämisoikeuden kunnioittaminen, vahingoittamisen 
välttäminen sekä yksityisyyden ja tietosuojan säilyttäminen. TENK:n ohjeistus koskee erityisesti tutkimusta, jonka kohteena on ihmistoimija. Verkkoaineistojen kohdalla tyypillistä on kuitenkin ihmisen, datan ja tekstin rajan hämärtyminen, joka aiheuttaa haasteita eettisten ongelmatilanteiden havaitsemisessa (Markham \& Buchanan 2012; Turtiainen \& Östman 2013).

Tutkijalla on velvollisuuksia myös muita kuin tutkittavia kohtaan. Sosiaalista mediaa käytetään yhä enemmän tutkimusten julkaisukanavana, jossa tutkimuksen tuloksia viestitään laajalle yleisölle. Tällöin mielenkiinnon kohteeksi nousee, millä tavalla tutkimuksen tuloksia esitellään usein rajatussa mitassa, jossa kaikkia siihen liittyviä näkökohtia ei voi tuoda esille. Samoin on syytä kiinnittää huomiota tapaan, jolla tiede ja tutkimus itsessään esitellään sosiaalisen median usein helposti ryöpsähtävissä keskusteluissa.

Tässä katsauksessa keskitymme kysymyksiin, jotka koskevat sosiaalisesta mediasta ammentavan tai sitä hyväksi käyttävän tutkimuksen tekemistä kolmessa tutkimuksen vaiheessa. Ensimmäinen vaihe on sosiaalisessa mediassa tapahtuva tutkimusaineiston kerääminen, jossa korostuvat kysymykset tutkittavien suostumuksesta. Toinen vaihe on tutkimusaineiston analyysi, jossa tutkittavien yksityisyyden suojaaminen on olennaisessa roolissa. Kolmas vaihe on tutkimuksen ja sen tulosten julkaiseminen sekä niistä käytävä keskustelu sosiaalisessa mediassa, jossa keskeisiä ovat hyvää viestintää ja tieteen läpinäkyvyyttä edistävät käytännöt.

\section{Tutkimusaineiston keruu sosiaalisesta mediasta}

Sosiaalinen media on monipuolinen alusta tutkimusaineiston keruuseen (esim. Laaksonen, Matikainen \& Tikka 2013). Yleisimpiä aineiston keruutapoja on kaksi. Yhtäältä tutkittavia rekrytoidaan julkaisemalla tiedote tai kutsu tutkimukseen yhdellä tai useammalla sosiaalisen median monista kanavista. Toisaalta tutkimusaineistoja myös kerätään sosiaalisessa mediassa tuotetusta materiaalista, kuten esimerkiksi blogikirjoituksista sekä kommenteista tai keskustelupalstan sisällöistä. Kyselyssä annettuihin tietoihin ja verkkoaineistoihin liittyvä suostumus sekä yksityisyyden suojelu ovat keskeisimpiä aineiston keruuseen liittyviä eettisiä kysymyksiä.

Tutkijan on huomioitava sosiaalisen median alustoihin liittyvät käyttöehdot sekä tekijänoikeudelliset kysymykset. Vaikka tekijänoikeudet eivät yleensä rajoita aineistojen tutkimuskäyttöä, voi tallennusalustoihin liittyä tekijänoikeudellisia rajoituksia (ks. Terkamo-Moisio ym. 2016). Tulosten julkaisemisessa voidaan myös rikkoa tekijänoikeuksia. Tutkijan on lisäksi syytä tutustua verkkopalveluiden käyttöehtoihin. Ne asettavat usein reunaehtoja materiaalin tutkimuskäytölle sekä rajoittavat koneellisesti ladattavan aineiston saatavuutta joko suojellakseen käyttäjien yksityisyyttä tai omaa liiketoimintaansa. Myös tulosten julkaisemisessa voidaan rikkoa käyttöehtoja. Käyttöehtoihin on syytä tutustua tarkkaan, sillä ne voivat olla myös epäjohdonmukaisia ja moniselitteisiä (ks. Moreno ym. 2013). Käyttöehtojen rikkomisesta rangaistuksena on usein ainoastaan sulkeminen palvelun ulkopuolelle. Jos käyttäjät kuitenkin ovat perehtyneet käyttöehtoihin, he voivat odottaa, että niiden sisältämien kieltojen tai rajoitusten mukaisesti verkkopalveluiden sisältöjä ei käytetä tutkimukseen.

Tutkittavia rekrytoitaessa tutkijan on pohdittava tietoon perustuvan suostumuksen toteutumista sosiaalisessa mediassa kerättävän aineiston yhteydessä. Suostumuksen saaminen ei useimmissa konteksteissa ole ongelma, jos vain käyttäjiin on mahdollista 
saada yhteys. Päinvastoin käyttäjät ovat tottuneet siihen, että heiltä pyydetään suostumusta erilaisten tietojen tallentamiseen tai hyödyntämiseen. On esitetty, että sosiaalisen median käyttäjät ovat tietyllä tapaa ehdollistuneet "hyväksy"-painikkeen painamiseen sisältöä lukematta (Kosinski ym. 2015). Tutkimusetiikan näkökulmasta tämä voi muodostaa riskin sekä tutkijalle että tutkittavalle.

Aineistoa kerätessä olisikin pyrittävä herättämään lukijan mielenkiinto itse viestin sisältöön. Mahdollisuuksia on monia: keskeisen tiedon voi esittää tiiviisti esimerkiksi pop-up-ikkunassa tai tutkimustiedotteeseen voi lisätä linkin, jonka takaa saa tarvittavia lisätietoja. Hyväksi koettu keino kyselyiden kohdalla on tietoisen suostumuksen pyytäminen juuri ennen vastausten lähettämistä. Tällöin osallistujan huomio voi kohdentua paremmin suostumuspyynnön sisältöön. Lisäksi vastaaja kyselyn täytettyään tietää, millaisten tietojen tallentamiseen ja käsittelyyn hän on suostumuksensa antamassa (Kosinski ym. 2015).

Sosiaalisen median julkisen aineiston käyttämistä varten tutkimuksessa ei usein ole tarvetta pyytää aineiston tuottajan suostumusta (ks. Wilkinson \& Thelwall 2011). Tulisiko tutkijan kuitenkin tiedottaa aineiston tuottajia tutkimuksestaan, kun aineisto koostuu jo aiemmin julkaistusta, heidän tuottamastaan materiaalista? Päätöstä tehdessä on arvioitava eri osapuolten oikeuksien sekä tutkimuksesta saatavan hyödyn tasapainoa.

Tutkimuksesta tiedottaminen voi antaa materiaalin tuottajille mahdollisuuden kieltäytyä osallistumasta tai vaikuttaa materiaaliin. Toisaalta eettisen tarkastelun näkökulmasta tärkeintä on tutkimuksesta aiheutuvan mahdollisen haitan minimointi. Tämä korostuu etenkin haavoittuvien ihmisryhmien sekä sensitiivisten tutkimusaiheiden kohdalla sekä kerättäessä aineistoa esimerkiksi suljetuista keskusteluryhmistä. Verkossa tutkimusta tehdään usein myös kontekstissa, jossa suostumuksen kerääminen kaikilta tutkittavilta on mahdotonta. Esimerkiksi historiallisten, anonyymien aineistojen kohdalla ei ole mitään keinoa saavuttaa kymmenen vuotta sitten mielipiteensä verkkoon kirjoittanutta nimimerkkiä. Toisaalta jos nimimerkin takana olevaa henkilöä ei voida saada selville, tunnistamisen mahdollisuus ja sitä myöten henkilölle aiheutuvan harmin riski on pieni.

\section{Sosiaalisen median aineistojen analysointi}

Sosiaalisen median aineistojen analyysin erityispiirre on se, että aineistoihin lähes väistämättä liittyy henkilötietoja. Monissa sosiaalisen median palveluissa profiili kytkeytyy suoraan oikeaan nimeen. Joidenkin tulkintojen mukaan esimerkiksi pelkkä Twitterin käyttäjänimi riittää yksilöimään käyttäjän henkilön. Tutkijan täytyy olla tietoinen sekä henkilötietojen käsittelyyn liittyvästä lainsäädännöstä että ihmistutkimuksen eettisistä periaatteista. Laki ei kuitenkaan ota kantaa kaikkiin tutkimuksen kannalta tärkeisiin eettisiin kysymyksiin. Sen näkökulmasta julkiset verkkokeskustelut ovat arkaluontoisinakin julkistettua tietoa, jonka käyttäminen aineistona on sallittua. Keväällä 2018 voimaan tuleva uusi EU:n tietosuoja-asetus näyttäisi jopa antavan entistä enemmän vapauksia henkilödatan tutkimuskäytölle (Maldoff 2016).

Kun sosiaalisessa mediassa julkaistuja sisältöjä käytetään tutkimusaineistona, tutkijan on pohdittava kysymystä materiaalien yksityisyydestä. Sosiaalisen median kontekstissa teknisesti julkisella aineistolla tarkoitetaan kaikkien saataville julkaistuja päivityksiä esimerkiksi avoimilla keskustelualustoilla tai ryhmissä. Selkeästi yksityistä aineistoa ovat esimerkiksi tutkijalle luottamuksellisesti lähetetyt viestit tai viestit suljetuissa ryhmissä. 
Yksityisen ja julkisuuden raja on kuitenkin häilyvä (ks. esim. Lange 2007; Lampinen 2014). Rajanveto on sidoksissa sekä tutkimusaiheeseen että materiaalien arkaluontoisuuteen. Vaikka materiaali on tietoisesti tuotettu alustalle, jossa se on julkisesti toisten saatavilla, voi tuottaja pitää sitä yksityisenä esimerkiksi materiaalin sisällön perusteella. Lisäksi palveluiden yksityisyysasetukset ja käyttöehdot voivat olla epäselviä tai muuttuvat niin usein, ettei käyttäjälle ole aina selvää, mitkä viesteistä ovat julkisia ja mitkä eivät.

Yksityisyys ei myöskään riipu ainoastaan aineiston tuottaneen käyttäjän omista näkemyksistä. Aineisto voi esimerkiksi sisältää yksityiseksi katsottavaa tietoa toisista ihmisistä. Joskus yksityisyyden voidaan katsoa olevan "ryhmän yksityisyyttä", jossa yksilö ei yksin päätä esimerkiksi viestin yksityisestä tai julkisesta luonteesta (ks. Ess 2015). Esimerkiksi perheen sisällä käytävän sinänsä julkisen verkkokeskustelun viesti voi muiden osallistujien mielestä olla luonteeltaan yksityistä, vaikka viestin kirjoittajan mielestä se ei kuuluisi yksityisyyden piiriin.

Yksityisyys on sinänsä suojeltava oikeus, mutta kokonaisuuden tarkastelussa merkityksellisiä ovat myös sen rikkoutumisen odotettavat seuraukset. Näin tutkijan on pohdittava myös aineiston kontekstia sekä sen arkaluontoisuutta. Verkkoaineistojen avulla voidaan käsitellä hyvinkin henkilökohtaisia ja arkaluontoisia teemoja, esimerkiksi uskontoon, poliittisiin mielipiteisiin tai seksuaaliseen suuntautumiseen liittyviä asioita. Sisällöstä huolimatta tutkimuskäyttö voi myös aiheuttaa aineiston tuottajassa kokemuksen, että häntä koskeva informaatio on siirtynyt pois hänen kontrollistaan (Elgesem 2015).

Yksityisyyden lisäksi toinen merkittävin tekijä aineiston käsittelyn eettisessä arvioinnissa on tutkittaville sekä muille mahdollisesti aiheutuva haitta. Association of Internet Researchersin eettiset ohjeet (Markham \& Buchanan 2012) painottavat vahingon aiheuttamiseen liittyvää harkintaa: mitä haavoittuvaisemmasta tutkittavasta tai teemasta on kysymys, sitä tarkemmin tutkijan velvollisuus on suojata tutkittaviaan:

"The greater the vulnerability of the community / author / participant, the greater the obligation of the researcher to protect the community / author / participant." (Markham \& Buchanan 2012, AolR ethical guidelines)

Sosiaalisen median aineistojen käsittelyssä olennaisinta on kehittää tarkka ymmärrys aineiston kontekstista. On mahdotonta antaa yleispätevää vastausta esimerkiksi kysymykseen "Aiheutuuko twiittien keräämisestä haittaa niiden lähettäjälle?" (vrt. Markham \& Buchanan 2012). Vastaus riippuu aina viestin lähettäjästä, aihepiiristä ja yhteiskunnallisesta kontekstista. Lopputulos riippuu myös analyysissa tehtävistä toimenpiteistä ja valinnoista.

Haitta voi tutkittavan lisäksi kohdistua myös tutkijaan. Myös Suomessa tutkijat ovat aineistojen keruun yhteydessä vastaanottaneet jopa uhkauksia. Tutkijan tulee varmistaa myös oman yksityisyytensä suojelu välttyäkseen haitalta, joka saattaa seurata sosiaalisen median hyödyntämisestä tutkimuksessa. Päätöksiä tehdessään tutkija joutuu usein pohtimaan tulosten luotettavuuden ja uskottavuuden sekä mahdollisen haitan välistä suhdetta.

Henkilöllisyyden suojaamiseen on käytössä useita keinoja, joista osa on käytössä jo aineiston keräämisen vaiheessa. Yksi keino on rajata rekrytointi koskemaan vain tiettyjä ryhmiä, jolloin tieto ei näy ulkopuolisille. Toinen keino on rajata tallennettavan tiedon määrää. Onko esimerkiksi vastaajan IP-osoitteen tallentaminen välttämätöntä? Mitkä 
taustatiedot ovat välttämättömiä tutkimuksen kannalta? Onko yksittäinen vastaaja turhaan tunnistettavissa tallennettavien tietojen perusteella?

Paras muistisääntö sosiaalisen median aineistojen analyysin parissa työskentelevälle tutkijalle on ajatella ja käsitellä aineistoja koko ajan henkilötietoina. Se tarkoittaa, että tutkittavien yksityisyyden suoja ja tietojen suojattu säilytys on varmistettava. Esimerkiksi suojaamaton pilvipalvelu on henkilötietoja sisältävälle tutkimusaineistolle väärä paikka. Tietojen tallentamisessa ja säilyttämisessä apumitaksi kannattaa ottaa Suomen laki henkilötietojen käsittelystä (Henkilötietolaki 1999/523).

Perinteinen keino turvata tutkittavien henkilöiden oikeuksia on aineiston anonymisointi. Monessa yhteiskuntatieteellisessä tutkimuksessa on kuitenkin oleellista tietää, kuka viestin on kirjoittanut. Esimerkiksi yhteiskunnallisen vallankäytön tutkiminen ilman lähettäjätietoja on mahdotonta. Silti on hyvä miettiä myös tutkimusprosessin aikana tarkasti, onko tutkijoiden tarpeen tietää tutkittavien identiteettejä.

Anonymisointi ei poista kaikkea henkilöllisyyden tunnistamisen mahdollisuutta. Eri aineistoja yhdistämällä voi olla mahdollista luoda pelottavan tarkkoja henkilöprofiileja arkaluontoisistakin aiheista. Lisäksi sosiaalisen median aineistojen kohdalla anonymisointi on osin kosmeettista. Julkisesta verkosta kerätty aineisto on kenen tahansa löydettävissä pelkästään tekstisisältöjen perusteella: esimerkiksi aineistolainaukseen poimitun twiitin lähettäjineen löytää Twitteristä hakukoneella.

Koska anonymisointi ei aina riitä tunnistettavuuden mahdollisuuden poistamiseen, haitan minimoinnin periaate täytyy pitää mielessä aina tutkimustulosten raportointiin ja julkaisemiseen asti. Tutkija joutuu käytännössä punnitsemaan, missä määrin hän esittää yleisölle aineistonäytteitä parantaakseen argumentaatiotaan ja missä määrin pyrkii turvaamaan tutkittavien anonymiteetin.

Kontekstin ymmärtäminen ja aineiston käytöstä mahdollisesti aiheutuvien haittojen pohtiminen on tärkein osa tutkijan eettistä ammattitaitoa. Digitaalisten aineistojen käyttöön pätevät kuitenkin pääasiallisesti samat varotoimenpiteet kuin ei-digitaalisten aineistojen kohdalla. Edellä mainitut käyttöehtoihin sisältyvät rajoitukset sekä niihin liittyvät aineiston tuottaneiden käyttäjien todennäköiset odotukset on otettava huomioon.

\section{Tutkimuksesta viestiminen sosiaalisessa mediassa}

Sosiaalinen media tarjoaa tutkijalle monipuolisia kanavia levittää tietoa tekemästään tutkimuksesta ja vaikuttaa eri aihepiireistä käytävään keskusteluun. Yksi sosiaalisen median peruspiirre on kuitenkin yhteisen päämäärän hämärtyminen. Kun periaatteessa kaikki voivat osallistua tasavertaisesti, mikään yksittäinen ryhmä ei määritä tapaa toimia. Tieteellisiin julkaisuihin, konferensseihin ja luentoihin tottunut tutkija voi pitää tilannetta toivottomana. Kun muut eivät jaa tutkijan tarkoitusta oppia ja löytää uutta tietoa uudesta, usein monimutkaisesta asiasta, osallistuminen keskusteluun voi näyttäytyä turhana.

Sitä se ei ole. Sosiaalista mediaa käytetään vaikuttamiseen joka tapauksessa (Jantunen 2015). Asialla ovat sekä ihmiset että algoritmit - tavoilla, joita emme edes huomaa. Jos tutkijat kääntävät tälle ilmiölle selkänsä, keskustelu ja tiedonvälitys jätetään muiden tahojen haltuun. On turha odottaa, että laajempi yleisö tulee mukaan asiantuntijoiden omille foorumeille. Siksi tutkijoiden pitäisi osata asemoida itsensä keskustelu- 
kumppaniksi suuren yleisön pariin sosiaalisessa mediassa. Vaikka tutkimukselle ominainen kriittinen tarkastelu on tarpeen myös silloin, kun sosiaalista mediaa käytetään tutkimuksesta viestimiseen (McClain \& Neeley 2014), on kuitenkin nähtävissä, että julkinen näkyvyys ja rakentava keskustelu verkossa hyödyttävät tutkijoita monin tavoin (Bik \& Goldstein 2013, Poutanen \& Laaksonen 2015). Suurin este sosiaalisen median käytölle on yleensä aikapula. Tässä yhteydessä on syytä ottaa vertailukohdaksi perinteisemmät kanavat, joihin tutkijat panostavat runsaasti, mutta ilman vastaavaa vaikuttavuutta ja näkyvyyttä (ks. Bik \& Goldstein 2013).

Tieteilijät ovat kauan julkaisseet työnsä toisille tieteilijöille, eivätkä ympäröivät rakenteet ole tukeneet muunlaista toimintaa. Kansantajuistaminen ja tutkimuksen popularisointi on tapahtunut tietokirjoissa. Sosiaalinen media puolestaan on luonteeltaan vuoropuhelua, ei yksipuolista informointia. Yleisöä voi saavuttaa vain osallistumalla keskusteluun - puhumalla toisia kiinnostavista aiheista tai nostamalla esiin uusia tärkeiksi koettuja aiheita.

Usein keskustelu edellyttää kompromisseja tieteellisessä työssä ja sen raportoinnissa keskeisten tarkkuuden, perusteellisuuden ja dokumentoinnin vaatimusten suhteen. Erityisen kimurantti kohta on sosiaalisen median (usein teknisestikin) rajattu mitta. Kun tutkija ei voi esittää kaikkia varaumia tutkimuksen ja sen tulosten suhteen, hän on helposti liian räväkkä. Tutkimuksen tuloksia on usein pakko yksinkertaistaa, mutta liiallinen yksinkertaistaminen ei sovi tieteeseen - ja voi rapauttaa asiantuntijuuden arvostuksen (ks. Raevaara 2016). Sosiaalisessa mediassa voi syntyä myös houkutus tavoitella näkyvyyttä jopa tieteellisen integriteetin kustannuksella. Kompromisseille on syytä asettaa rajat ja noudattaa niitä senkin uhalla, ettei tutkimus saa sitä huomiota, jonka sille toivoisi. Kompromissit ovat tarpeen myös keskustelun tavoitteiden osalta. Tutkijan ei kannata ajatella, että keskustelun päätepisteenä muut osallistujat ovat tietoisia ja vakuuttuneita kaikesta siitä, mitä hän omasta aihepiiristään tuntee. Tutkija on tutkija juuri siksi, että hänellä on asiantuntijuutta, jota muilla ei ole.

On selvää, että kaikki eivät vakuutu parhaastakaan tieteellisestä tutkimuksesta, vaikka sen tuloksia ja menetelmiä esittelisi asiallisesti ja perustellen. Sosiaalisen median kontekstissa on pidettävä mielessä, että käydyn keskustelun näkevät ja lukevat ehkä sadat tai tuhannet muut. Tärkeintä on, että tietoa ja ymmärrystä tieteestä siirtyy keskustelussa eteenpäin - tieto saatetaan virtaamaan. Popularisoinnilla ja keskustelulla ei ole merkitystä, ellei sillä tavoita laajempaa ja erilaista yleisöä kuin varsinaisella tieteellisellä julkaisutoiminnalla. Viimeiseksi on tärkeää muistaa, että aktiivinen osallistuminen sosiaalisessa mediassa ei ole jatkuva palvelulupaus. Tutkijan ei tarvitse olla saatavilla vuorokauden ympäri, eikä asiattomiin viesteihin tarvitse vastata.

Tutkija miettii usein tutkimuksen julkaisua tulosten esiin tuomisena. Parhaimmillaan osallistuminen sosiaalisessa mediassa kasvattaa kuitenkin myös ymmärrystä itse tieteestä - sen tavoitteista, menetelmistä, käytännön työtavoista ja tekijöistä. Tutkija ei pelkästään välitä tietoa. Hän tekee tieteenalansa käytäntöjä läpinäkyviksi, laajentaa verkostojaan ja oppii samalla itsekin uutta. Esimerkiksi kansalaisten osallistuminen ja joukkovoiman tehokas hyödyntäminen tieteen tekemiseen edellyttää valmiuksia ja yhteyksiä, joita sosiaalisen median aktiivisuus luontevasti tutkijoille avaa (ks. Franzoni \& Sauermann 2014).

Osa tiedettä ja tutkimusta koskevan ymmärryksen lisäämistä on antaa tunnustus sille, jolle se kuuluu. Kenen tutkimuksesta tai oivalluksesta on kyse? Sosiaalisessa medi- 
assa on kyse myös verkostojen näkyväksi tekemisestä. Kohteliaisuusnormit ovat vahvasti näkyvillä perinteisissä tieteellisissä artikkeleissa (ks. Kinnunen \& Löytty 2006). Niitä ei ole syytä unohtaa muissakaan yhteyksissä, olivat kyseessä sitten blogikirjoitukset (Blanchard 2011) tai postaukset Facebookiin ja Twitteriin. Muiden sisältöjen jakaminen ja inspiraation ja tuen mainitseminen tuovat esiin tieteen yhteisöllisen luonteen - sen, että tulokset eivät olleet vain yhden tutkijan tuottamia.

Tieteen yhteisöllisyys osoittaa myös sen, kuinka tiede ylittää yksittäisen tutkijan perustellunkin näkökulman, hypoteesin tai teorian. Perinteisen tiedon portinvartijoiden aikaan oli tapana, että tutkija esiintyi aihepiirinsä lähes erehtymättömänä auktoriteettina. Nyt uskottavuutta pikemminkin lisää, jos omat väitteet ovat avoimesti erehtyväisiä ja korjaamiselle alttiita. Tiedettä luonnehtii fallibilismi: mikä tahansa syvälle juurtunutkin käsityksemme voi vaatia korjausta. Todellinen tieteentekijä ja asiantuntija on valmis avoimesti kyseenalaistamaan, haastamaan ja korjaamaan myös omia näkemyksiään - ja erottuu näin edukseen. Sosiaalinen media ja julkinen keskustelu pursuaa erilaisia ei-tieteellisiä auktoriteetteja, jotka eivät tähän kykene.

\section{Kirjallisuus}

Bik, Holly M. \& Goldstein, Miriam C. (2013). An Introduction to Social Media for Scientists. PLoS Biol11: 4, https://doi.org/10.1371/journal.pbio.1001535

Blanchard, Anita (2011). Science blogs in research and popularization of science: Why, how and for whom? Teoksessa Cockell M., Billotte J., Darbellay F., Waldvogel F. (toim.), Common Knowledge: The Challenge of Transdisciplinarity, pp. 219-232. Lausanne, Switzerland: EPFL Press.

Elgesem, Dag (2015). Consent and information - ethical considerations when conducting research on social media. Teoksessa Fossheim, Hallvard \& Helene Ingierd (toim.) Internet Research Ethics. Cappelen Damm Akademisk.

Ess, Charles (2015). New selves, new research ethics? Teoksessa Fossheim, Hallvard \& Helene Ingierd (toim.). Franzoni, Chiara \& Sauermann, Henry (2014). Crowd science: The organization of scientific research in open collaborative projects. Research Policy, 43: 1, 1-20.

Euroopan parlamentti ja neuvosto (2016). Asetus (EU) 2016/679 luonnollisten henkilöiden suojelusta henkilötietojen käsittelyssä sekä näiden tietojen vapaasta liikkuvuudesta. Saatavilla http://ec.europa.eu/iustice/data-protection/reform/files/regulation oj en.pdf

Henkilötietolaki 1999/523. Annettu Helsingissä 22.4.1999.

Jantunen, Saara (2015). Infosota. "Iskut kohdistuvat kansalaisten tajuntaan". Keuruu: Otavan Kirjapaino.

Kinnunen, Merja \& Löytty, Olli (2006). Reilua julkaisutoimintaa. Teoksessa Hallamaa ym. (toim.) Etiikkaa ihmistieteille, s. 334-346. Helsinki: Suomalaisen kirjallisuuden seura.

Kosinski Michail, Matz, Sandra C., Gosling, Samuel D., Popov, Vesselin \& Stillwell, David (2015). Facebook as a research tool for the social sciences: Opportunities, challenges, ethical considerations, and practical guidelines. American Psychologist 70: 6, 543-556.

Laaksonen, Salla-Maaria, Matikainen, Janne \& Tikka, Minttu (2013). Tutkimusotteita verkosta. Teoksessa: Laaksonen, Salla-Maaria., Matikainen, Janne. \& Tikka, Minttu (toim.). Otteita verkosta. Verkon ja sosiaalisen median tutkimusmenetelmät. Tampere: Vastapaino, s. 931.

Lampinen, Airi (2014). Interpersonal Boundary Regulation in the Context of Social Network Services. Väitöskirja, Helsingin yliopisto, Sosiaalipsykologia. Saatavilla: https://helda.helsinki.fi/handle/10138/42272 
Lange, Patricia G. (2007). Publicly Private and Privately Public: Social Networking on YouTube. Journal of Computer-Mediated Communication, 13: 1, 361-380.

http://doi.org/10.1111/j.1083-6101.2007.00400.x

Maldoff, G. (2016). How GDPR changes the rules for research. The International Association of Privacy Professionals. Saatavilla: https://iapp.org/news/a/how-gdpr-changes-the-rulesfor-research/\# [Viitattu 9.11.2017]

Markham, A. \& Buchanan, E. (2012). Ethical decision-making and internet research. Recommendations from the AolR ethics working committee (versio 2.0). Saatavilla: http://aoir.org/reports/ethics2.pdf |Viitattu 15.2.2018]

McClain, Craig \& Neeley, Liz (2014). A critical evaluation of science outreach via social media: its role and impact on scientists. F1000Research, 3: 300, 1-8.

Moreno, Megan A., Natalie Goniu, Peter S. Moreno \& Douglas Diekema (2013). Ethics of Social Media Research: Common Concerns and Practical Considerations. Cyberpsychology, Behavior and Social Networking 16(9): 708-13.

Poutanen, Petro \& Laaksonen, Salla-Maaria (2015). "Miksi vaivautua?" Tutkimusmaailman trendit haastavat tutkijat viestimään työstään. Tiedeviestintä - opas tutkijalle. Helsingin yliopisto. http://blogs.helsinki.fi/tiedeviestinta/2015/05/06/miksi-vaivautua-tutkimusmaailman-trendit-haastavat-tutkijat-viestimaan-tyostaan/ [Viitattu 30.9.2017]

Raevaara, Tiina (2016). Tajuaako kukaan? Opas tieteen yleistajuistajalle. Tampere: Vastapaino. Terkamo-Moisio, Anja, Halkoaho, Arja \& Pietilä, Anna-Maija (2016). Sosiaalinen media tieteellisessä tutkimuksessa - tutkimuseettisiä näkökulmia. Sosiaalilääketieteellinen aikakauslehti., 53: 2, 141-143.

Turtiainen, Riikka \& Östman, Sari (2013). Verkkotutkimuksen eettiset haasteet: Armi ja anoreksia. Teoksessa: Laaksonen, Salla-Maaria., Matikainen, Janne. \& Tikka, Minttu (toim.). Otteita verkosta. Verkon ja sosiaalisen median tutkimusmenetelmät. Tampere: Vastapaino. s. 47-65.

Tutkimuseettinen neuvottelukunta (TENK): Eettinen ennakkoarviointi inmistieteissä. Saatavilla: http://www.tenk.fi/fi/eettinen-ennakkoarviointi-ihmistieteissa [Viitattu 15.2.2018]

Wilkinson, David \& Mike Thelwall (2011). Researching personal information on the public web. Social Science Computer Review 29:4, 387-401.

Zimmer, Michael \& Kinder-Kurlanda, Katharina (2017). Internet Research Ethics for the Social Age. Peter Lang Publishing.

Zimmer, Michael (2015). Research ethics in the big data era: Addressing conceptual gaps for researchers and IRBs. Beyond IRBs: Ethical Review Processes for Big Data Research työpaja, 20.12.2015. Saatavilla: https://bigdata.fpf.org/wp-content/uploads/2015/12/Zimmer-Research-Ethics-in-the-Big-Data-Era.pdf [viitattu 15.11.2017]

Östman, Sari \& Turtiainen, Riikka (2016). From research ethics to researching ethics in an online specific context. Media and Communication 4: 4, 66-74.

\section{Viitteet}

${ }^{1}$ aoir.org
${ }^{2}$ http://www.tenk.fi/fi/eettinen-ennakkoarviointi-ihmistieteissa 